2009 Testimonials

"Excellent meeting. I always come back intellectually challenged and picking up new tricks, tips and pointers."'

"This was one of the best meetings I have attended in my entire career. Putting surgeons together with cardiologists to discuss controversial topics is a superb format."

\section{REGISTRATION}

Space is limited, register today at www.acc.org/HVS2010

Please note that, if you are a member of $\underline{A A T S}, \underline{A S E}, \underline{S C A I}$ or STS, you must submit your registration form through fax or mail to receive the member rate.

\section{ACCREDITATION}

\section{Physicians}

The American College of Cardiology is accredited by the Accreditation Council for Continuing Medical Education to provide continuing medical education for physicians.
The ACCF designates this educational activity for a maximum of 18.25 AMA PRA Category 1 Credits $^{\mathrm{TM}}$. Physicians should only claim credits commensurate with the extent of their participation in the activity.

\section{Nurses}

The American College of Cardiology Foundation is accredited as a provider of continuing nursing education by the American Nurses Credentialing Center's Commission on Accreditation.

The ACCF designates this educational activity for a maximum of 18.25 continuing education hours. Requirements for successful completion are attendance in a session in its entirety and completing the evaluation tool. Each attendee should only claim credits commensurate with the extent of their participation in the activity.

While offering credits noted above, the program is not intended to provide extensive training or certification in the field.

\title{
The Western Thoracic Surgical Association
}

\section{Applications for Membership}

Applications for membership in the Association must be received by the Membership Committee Chair no later than March 1, 2011, to be considered at the 2011 Annual Meeting. Applicants must be sponsored by three members of the Association who are not members of the Membership Committee. Application forms will be issued only to sponsoring members.

Address correspondence to:

Chair, Membership Committee

\author{
The Western Thoracic Surgical Association \\ 900 Cummings Center \\ Suite 221-U \\ Beverly, MA 01915 \\ 978-927-8330; fax: 978-524-8890 \\ wtsa@prri.com
}

\section{WTSA 37th Annual Meeting}

\section{Save the Date!}

June 22-25, 2011

The Broadmoor Hotel

Colorado Springs, Colorado

\section{The American Board of Thoracic Surgery}

\section{Notices}

The part I (written) examination was held on December 3. It is planned that this examination will be given at multiple sites throughout the United States using an electronic format. The closing date for registration is August 1 each year. Those wishing to be considered for examination must apply online at www.abts.org.

To be admissible for the Part II (oral) examination, a candidate must have successfully completed the Part I (written) examination.

A candidate applying for admission to the certifying examination must fulfill all the requirements of the Board in force

at the time the application is received. Please address all communications to the American Board of Thoracic Surgery, 633 North St Clair Street, Suite 2320, Chicago, IL 60611 (telephone: 312-202-5900).

\section{Requirements for Maintenance of Certification}

Diplomates of the American Board of Thoracic Surgery (ABTS) who plan to participate in the Maintenance of Certification (MOC) process must hold an unrestricted medical license in the locale of their practice and privileges in a hospital accredited by the JCAHO (or other organization recognized by the ABTS). In addition, a valid ABTS certificate is an absolute requirement for entrance into the Maintenance of Certification process. If your certificate has expired, the only 